\title{
Predicting post-absorptive protein and amino acid metabolism
}

\author{
Mark D. Hanigan ${ }^{1 *}$, Robin R. White ${ }^{1}$, Sebastian I. Arriola Apelo ${ }^{1}$, Michelle Aguilar ${ }^{1}$, Kari A. \\ Estes $^{1}$, Adelyn Myers ${ }^{1}$
}

${ }^{1}$ Virginia Tech, Department of Dairy Science, Blacksburg, VA, USA.

ABSTRACT - Sustainable production of adequate quantities of food to support a growing human population is a worldwide goal. Under current feeding conditions in the United States, dairy cattle convert dietary nitrogen to milk nitrogen with $25 \%$ efficiency. The remaining $75 \%$ is excreted, which contributes to air and water quality problems and reduces economic performance of the industry. Efficiency could be improved to $29 \%$ if protein was given to just meet current NRC requirements. Additional improvements may be achievable, but only with improved knowledge of amino acid (AA) requirements. The current metabolizable protein requirement model overestimates true requirements due to lack of knowledge of AA supply and requirements and to intrinsic limitations in system data and assumptions. Existing protein supply models based on passage and degradation rates are biased, which undermines predictions of AA supply. The use of an equation driven solely by protein solubility of each ingredient in the diet with no consideration of the effects of passage rate yielded unbiased predictions with significant improvements in precision. However, this still leaves a problem in predicting the AA composition of the ruminally undegraded protein (RUP). Current models generally assume that RUP AA composition equals the parent ingredient composition, but assessments of RUP AA composition indicate that this is false. Thus, bias is being introduced into predictions of the absorbed AA supply, which hampers derivation of estimates of AA digestion and absorption from the small intestine. Emerging isotope-based methods hold promise in allowing assessment of AA availability from individual ingredients in vivo, which will allow construction of a database of true ingredient AA bioavailabilities. These efforts will eventually allow development of more robust predictions of AA supply. On the AA requirement side, numerous data indicate that the efficiency of metabolizable protein use for lactation is variable and maximally $45 \%$, whereas most models assume an efficiency of $65 \%$ or greater. The efficiencies of individual AA are centered on the protein efficiency value with those lower in efficiency, likely being provided in large excess. A better representation of the use efficiency of individual AA would allow improvements in overall animal $\mathrm{N}$ efficiency. Variable efficiency is driven by regulatory mechanisms that control protein synthesis in response to the supply of energy and individual AA and circulating concentrations of hormones and these drivers act independently and additively. Under this theory, protein synthesis can respond to nutrients other than the one identified as most limiting. Reflecting this regulation in our requirement models will allow better prediction of AA efficiency and enable construction of diets that minimize excess of individual AA by optimizing the energy and hormonal signals to improve $\mathrm{N}$ efficiency. Models of such an interacting system have been developed and shown to be superior in performance to models based on current paradigms.

Key Words: amino acids, lactation, metabolizable protein, milk urea nitrogen, nutrient requirements

\section{Introduction}

Providing sufficient high-quality protein for the future is a global challenge. Global population is projected to exceed nine billion people by 2050 (U.S. Census Bureau, 2008), with substantial increases in demand for food energy and protein. Animal protein will play a role in meeting food

Received: December 27, 2016

Accepted: July 30, 2017

*Corresponding author: mhanigan@vt.edu

Copyright (c) 2018 Sociedade Brasileira de Zootecnia. This is an Open Access article distributed under the terms of the Creative Commons Attribution License (http://creativecommons.org/licenses/by/4.0/), which permits unrestricted use, distribution, and reproduction in any medium, provided the original work is properly cited. demand (Delgado, 2003) and continued animal nutrition research is vital to maximize the efficiency and minimize the environmental footprint of animal protein production. Food production resources are already limited (Rockström et al., 2009; Hertel, 2011) and livestock feed conversion efficiency must be improved to help meet future food demand while minimizing environmental impact.

Protein, which is the source of $\mathrm{N}$ waste and the associated environmental pollution, is an expensive dietary nutrient (Table 1), representing approximately $42 \%$ of the cost of a lactating cow ration (St-Pierre, 2012). The reduction of dietary protein levels could potentially result in decreased demand for high-protein ingredients, reduced price of those ingredients, and the diversion of acreage to 
higher yielding crops, such as maize, instead of growing oilseeds.

In a survey carried out on 103 large scale dairies across the US $(613 \pm 46$ cows; $34.5 \pm 0.3 \mathrm{~kg}$ of milk per cow per day), nutritionists reported feeding diets with $17.8 \pm 0.1 \%$ crude protein (CP) (Caraviello et al., 2006). A meta-analysis of 846 experimental diets showed a similar mean diet $\mathrm{CP}$ content and identified that conversion efficiencies for dietary and metabolizable $\mathrm{N}$ (based on NRC, 2001) to milk protein averaged 24.6 and $42.6 \%$, respectively (Hristov et al., 2004). Assuming the same dietary conditions $(22.1 \mathrm{~kg} /$ day dry matter intake (DMI) and $17.8 \% \mathrm{CP}$ ) over a 10 -month lactation, the nine million dairy cattle in the US (Livestock, Dairy, and Poultry Outlook: August 2012, LDPM-218, Dairy Economic Research Service, USDA) would excrete 1.3 million metric tons ( $\mathrm{mmt}$ ) of $\mathrm{N}$ per year. Efficiency could be increased to approximately $29 \%$ if animals were fed according to NRC (2001) requirements $(\sim 16 \% \mathrm{CP})$. If a dietary protein conversion efficiency of $35 \%$ could be achieved with no change in milk protein output, excreted $\mathrm{N}$ would be reduced $39 \%$ to $0.51 \mathrm{mmt}$. Additionally, White (2016) estimated that a $5 \%$ improvement in protein use efficiency would reduce land use, water use, and greenhouse gases by $8 \%$ compared with US average production.

Dietary protein is used to support microbial growth in the rumen. The combination of microbial protein flow from the rumen and ruminally undegraded dietary protein (RUP) is used for maintenance and productive functions, such as milk protein synthesis, and represents the majority of the metabolizable protein (MP) supply to the animal. Several models, such as the NRC Nutrient Requirement models (NRC, 1989, 2001), estimate ruminal and animal $\mathrm{N}$ requirements and dietary supply of ruminally degradable protein (RDP) and RUP, allowing users to match supply to animal requirements. These systems are commonly used in ration-balancing software. Because the NRC model is widely used, it is a primary determinant of protein use in dairy diets, particularly in the US. Regardless of the model used, it is important that the model be precise and accurate if $\mathrm{N}$ efficiency is to be optimized.

\section{Metabolizable protein supply and requirement predictions}

Although we commonly state animal $\mathrm{N}$ requirements in terms of MP, the true requirements are for the specific amino acids (AA) resident in that protein. Because there is diversity of AA composition in the absorbed protein, stating the requirements in MP units inherently forces a certain level of over-prediction of requirements to compensate for variation in AA composition of that protein. This is perhaps most apparent when feeding diets constructed largely from maize products which are inherently low in lysine. Such a diet could be created to meet MP requirements, but animals may still respond to the addition of a protected lysine source or more protein that also provides lysine to the ration. When these types of data are mixed with all other experiments in the literature and subjected to statistical analyses to derive MP requirements, the loss in production associated with a specific amino acid deficiency forces the statistical algorithm to solve to a higher MP requirement than would be necessary if the diet contained a perfect mix of amino acids. For example, pigs can achieve efficiencies of absorbed protein deposition in muscle protein of $85 \%$ when fed a diet perfectly matched to their AA requirements (Baker, 1996) as compared with 43\% efficiency of conversion of MP to milk protein in lactating cows (Hristov et al., 2004). Therefore, it is known that MP requirements are greater than needed to compensate for variable AA supply. Thus, animals could successfully be fed a lower MP diet if the AA composition of that diet was better matched to AA requirements as demonstrated by Haque et al. (2012) using diets with less than $13 \%$ CP. As the cost of RUP is generally two to three-fold greater than the cost of RDP (Knapp, 2009), being able to reduce dietary RUP is of great economic interest.

Aside from the question of balancing for AA to achieve greater efficiency, there are additional problems with the NRC (2001) MP requirement system equations. Obviously, one would expect the model to predict requirements at all levels of production with the same precision. For example,

Table 1 - Nutrient values based on central Ohio ingredient prices. Adapted from St-Pierre and Knapp ${ }^{1}$.

\begin{tabular}{lcccrrr}
\hline Nutrient & $09 / 2008$ & $08 / 2009$ & $10 / 2010$ & $09 / 2011$ & $09 / 2012$ \\
\hline NEL $(\$ / M c a l)$ & 0.145 & 0.103 & 0.121 & 0.166 & 0.194 & 0.115 \\
MP $(\$ / \mathrm{kg})$ & 0.643 & 1.026 & 0.610 & 0.617 & 1.097 & 1.401 \\
neNDF $(\$ / \mathrm{kg})$ & -0.430 & -0.566 & -0.159 & -0.181 & -0.267 & -0.090 \\
eNDF $(\$ / \mathrm{kg})$ & -0.163 & -0.099 & -0.002 & 0.178 & -0.024 & 0.130 \\
\hline
\end{tabular}

${ }^{1}$ www.dairy.osu.edu/bdnews.

$\mathrm{NE}_{\mathrm{L}}$ - Net energy of lactation; MP - metabolizable protein; NDF - neutral detergent fiber; neNDF - non-effective NDF; eNDF - effective NDF. 
if the precision of the system at $25 \mathrm{~L}$ of milk/day is plus or minus $15 \%$, then one should expect similar precision at 35 and $40 \mathrm{~L}$ of milk. Unfortunately, this is not the case. The model overpredicts the amount of MP allowable milk at high levels of production, while predicting more accurately at lower levels (Figure 1). Thus, when using the model, one may need to balance for slightly greater amounts of MP in the diet if working with high-producing cows assuming that requirements for maintenance and gestation are correct.

The errors in predicting milk yield responses to varying MP supply are driven in part by poor predictions of MP supply (Figure 2) (Roman-Garcia et al., 2016; White et al., 2016a; White et al., 2017a; White et al., 2017b). The model overpredicts RUP flow on average by $40 \mathrm{~g} \mathrm{~N} /$ day for a typical animal and the error increases as RUP flow increases (Figure 2), indicating fundamental problems in model structure, which contributes to the observed bias in predicting milk production. Bateman et al. (2005) and Broderick et al. (2010) observed similar problems. Correlation analyses indicated the problem was associated with passage rate $(\mathrm{Kp})$ estimates. The $\mathrm{Kp}$ equations used by the NRC (2001) were biased compared with $\mathrm{Kp}$ measurements from studies using indigestible neutral detergent fiber (NDF) as a marker (Krizsan et al., 2010). A recent study of $\mathrm{Kp}$ on forage-based diets also supports bias in prediction of particulate Kp (Gregorini et al., 2015). Attempts to address the problem by refitting the $\mathrm{Kp}$ equation or bias adjusting in situ determined $\mathrm{Kd}$ estimates failed to generate any substantial gains in model performance (White et al., 2017a). As a point of comparison, a simple model predicting non-ammonia, non-microbial nitrogen from $\mathrm{N}$ intake using a single slope and intercept had a lower root mean square error (RMSE) than the NRC (2001) model even after re-derivation of

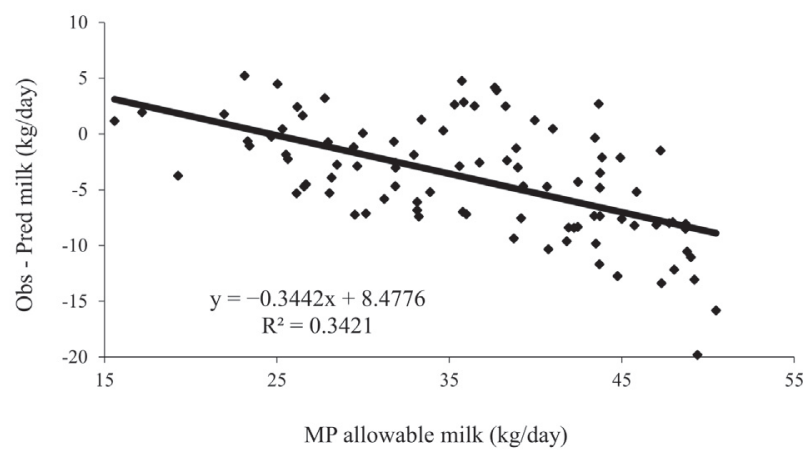

Obs - Pred $=$ observed - predicted.

Figure 1 - Residual errors (Obs - Pred) associated with predictions of metabolizable protein (MP) allowable milk yields by the NRC (2001) model. Adapted from NRC (2001). model parameters. However such a simple representation would fail to capture known effects of ingredients that are particularly susceptible or resistant to ruminal degradation (Cecava et al., 1988; Erasmus et al., 1992; Cunningham et al., 1993; Erasmus et al., 1994; Abreu et al., 2004) and, thus, do not help to achieve our end goals. Despite the clear limitations in the $\mathrm{ABC} / \mathrm{Kd}$ system used by the $\mathrm{NRC}$, there does seem to be value in the fractionation scheme. Fitting digestion coefficients for each fraction within fairly broad feed categories, grasses, legumes, energy concentrates, plant protein sources, animal protein sources, etc. yielded a system that performed considerably better than the existing NRC system (Figure 2) (White et al., 2017a).

A portion of the problem in predicting MP responses is also driven by the model assumption that the conversion of MP to milk protein, after subtraction of maintenance use, is a constant $65 \%$. In a summary of literature data, Lapierre et al. (2007) found that the highest efficiency was $43 \%$ and it declined from there as milk protein output (and MP supply) increased. Hanigan et al. (1998) summarized publications reporting responses to post-ruminally infused casein and found a similar maximal efficiency of conversion of about $45 \%$ with an average conversion efficiency of $22 \%$. Whitelaw et al. (1986) abomasally infused casein at three different levels and observed responses at each level with conversion efficiencies ranging from 40 , for the first increment, to $15 \%$, for the last increment. If the model were altered to reduce the efficiency of MP use for milk protein synthesis, this could address the slope bias problem (in

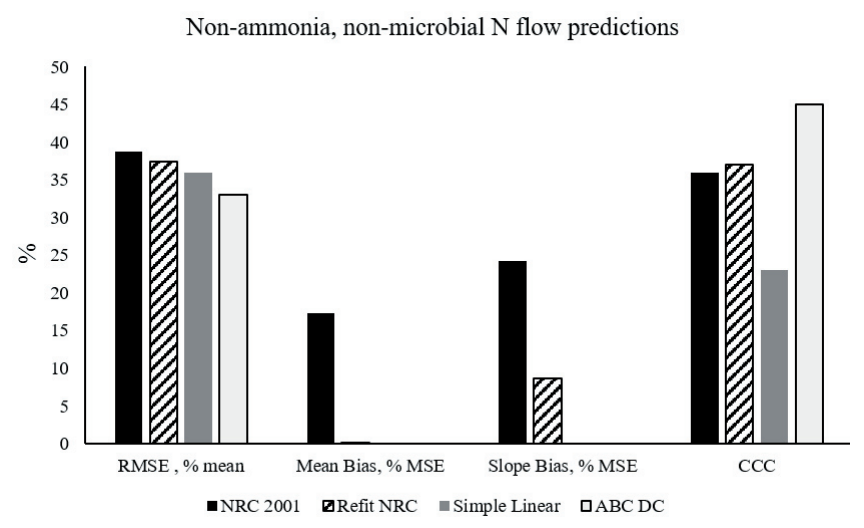

MSE - mean square prediction error; RMSE - square root of MSE; CCC - concordance correlation coefficient.

Figure 2 - Prediction errors for ruminal outflow of non-ammonia, non-microbial $\mathrm{N}$ by the NRC 2001 model. The NRC model (NRC, 2001) refit to literature data (refit NRC), a simple linear model with a constant digestion coefficient (Simple linear), or a model using static digestion coefficients for each of the $\mathrm{A}, \mathrm{B}$, and $\mathrm{C}$ protein fractions that were defined by feed category (ABC DC). Adapted from White et al. (2017a). 
Figure 1), in which each unit increase in MP supply results in an overprediction of the change in milk protein output. It may also introduce bias at the lower MP supply levels as the model predicts production at the lower input levels without bias. Introduction of mean bias associated with the change in MP efficiency would be indicative of a problem with estimates of the maintenance requirement.

Although not apparent (Figure 1), there is also nonlinear bias present in the system (Lapierre et al., 2007). Several efforts are in progress to address this variable efficiency problem. White et al. (2016b) demonstrated a substantial improvement in model performance when the efficiency of conversion of absorbed MP to milk protein was represented using a mono-molecular equation form with each of the essential AA and energy supply as substrates in the equation. This approach had the advantage of addressing both the nonlinear responses and the effects of individual AA on the efficiency of production (discussed further below). The limitation with this approach is that it is highly empirical and slopes on individual AA may be misrepresented outside the range of available data.

\section{Amino acid requirements}

The challenge of predicting AA supply and requirements for ruminants is much greater than for monogastric species. Flow of AA from the rumen is a function of the AA content of undigested feed protein, microbial protein, and sloughed digestive tract cells and secretions (NRC, 2001). Additionally, a portion of the protein and amino acids catabolized in the rumen and the body can be recaptured in amino acids and protein by ruminal microbes due to significant return of blood urea nitrogen to the rumen (Reynolds and Kristensen, 2008). The difficulty of predicting each of these entities has greatly hampered our ability to derive AA requirements based on performance data as it is done with swine and poultry.

We have recently adapted an approach used by Maxin et al. (2013) to assess the absorbed supply of each AA from individual dietary ingredients. The method makes use of a 2-h constant infusion of a ${ }^{13} \mathrm{C}$ labelled amino acid mixture derived from enriched algae to assess the entry rate of each AA. Data are interpreted using a 2-pool model representing slow and fast turnover pools. Fitting the model to the observed rise and fall of isotopic enrichment allows derivation of the turnover rate of each AA in both pools and thus the entry rates of each AA into the blood pool. The entry rate is the absorption rate for essential AA and absorption plus synthesis for non-essential and semi-essential AA (example of plots after model fitting in Figure 3). By diet substitution or regression, one can derive the rate of entry associated with an individual ingredient, provided it can be fed at a large enough inclusion rate to avoid propagation of errors (example of raw data in Figure 3). The infusate is introduced into the jugular vein and blood collection for isotope enrichment determinations occurs upstream from the infusate line or in the contralateral jugular vein. Thus, the measurements can be made with minimal animal preparation. Preliminary work indicates that entry rate errors of measurement are approximately $10 \%$. Application of this method should allow the generation of a table of AA bioavailabilities for all ingredients comparable to energy or CP tables. Such a table would greatly improve our knowledge of AA supply from RUP and avoid the current in situ challenges with assigning AA composition to the residue proteins.

Most of the progress that has been made in defining AA requirements for ruminants has occurred through the use of catheterized and cannulated animals, allowing the provision of AA post-ruminally (for example Haque et al., 2012). However, this is very intensive and expensive work. To date, we have amassed most information on methionine and lysine with histidine results appearing more recently (Rulquin et al., 1993; Korhonen et al., 2000; Noftsger and St-Pierre, 2003). For the remaining essential

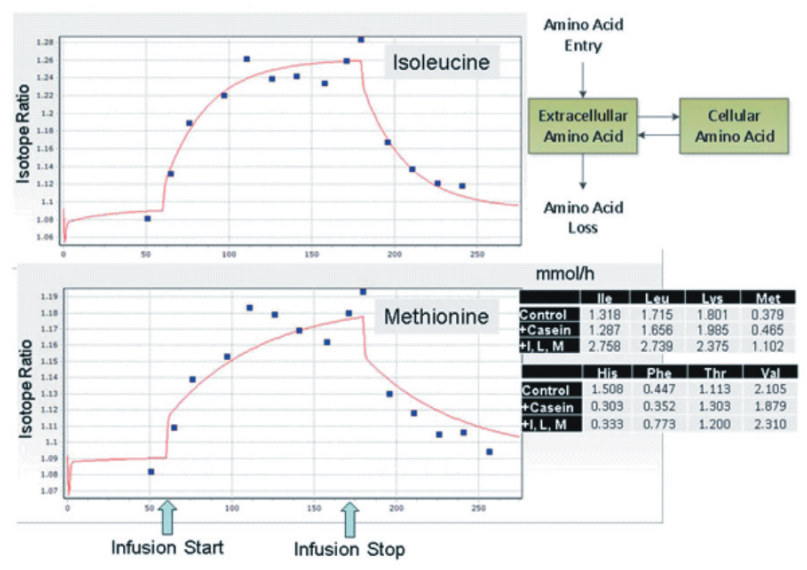

Ile - isoleucine; Leu - leucine; Lys - lysine; Met - methionine; His - histidine; Phe - phenylalanine; Thr - threonine; Val - value derived from model.

The model contained a split cellular AA pool to represent slow and fast turnover which yields the curvature to the enrichment as it approaches plateau. Mode simulations of the data are reflected by the solid red line after the model was fitted to the data. Amino acid entry rates for isoleucine, leucine, lysine, methionine, histidine, phenylalanine, threonine, and value derived from model fits to a single animal subjected to 3 treatments are presented in the table. The data are not adjusted for differences in DMI or for diet substitutions that occurred. +Casein and +I,L,M treatments were abomasal infusions of casein and a mix of isoleucine, leucine, and methionine, respectively which were substituted for soybean meal in the control diet. The control diet was $34 \%$ maize silage, $34 \%$ grass hay diet (DM basis) supplemented with soybean meal and vitamins and minerals with $23 \%$ CP. Animals were fed every $2 \mathrm{~h}$ for $18 \mathrm{~h}$ before and throughout the blood sampling period.

Figure 3 - Blood enrichment of isoleucine and methionine during the course of an isotope infusion experiment. 
AA, we are far from the level of understanding that swine and poultry nutritionists have achieved and are unlikely to achieve that level of understanding in the near future.

Because AA requirements are expressed as a percentage of MP supply, any problems with estimating MP efficiency are partially propagated in existing AA requirement equations and are likely contributing to the lack of accuracy and precision in those equations (NRC, 2001). Work at the tissue level, using multi-catheterized animals, has shown that liver and gut tissues appear to remove a constant fraction of AA from blood presented in each pass by that tissue. Because mammary tissue does not generally remove more than half of the AA presented to it, there is significant recycling to the gut and liver, resulting in additional removal. This is magnified as AA supply increases relative to energy supply, as the mammary tissue has the ability to change its removal of AA to meet its needs (Bequette et al., 2000). Therefore, if mammary tissue is presented with a good energy supply, it will be able to produce milk near its maximum potential and will increase its AA extraction efficiency to achieve this. The same will happen if energy is held constant and AA supply is reduced. Conversely, if the mammary tissue is presented with inadequate energy, it will reduce its use of AA and reduce extraction from blood (Hanigan et al., 2000). In the former case, AA extraction efficiency is increased, fewer AA are recycled to the liver and gut, and fewer are catabolized. In the latter case, mammary AA extraction efficiency decreases, more AA are recycled, and catabolism increases. Therefore, assuming a constant efficiency of post-absorptive AA use for milk protein synthesis is clearly wrong.

Work to define the mechanisms controlling mammary AA uptake and use for milk protein has progressed considerably over the past 15 years to the point where fairly robust mechanistic models of mammary metabolism have been constructed (Hanigan et al., 2000; Hanigan et al., 2001; Hanigan et al., 2002; Castro et al., 2016), which capture the independent and additive effects of key essential AA, energy supply, and insulin. Important concepts in these mechanistic models have been leveraged in preliminary work to develop an equation to describe variable MP efficiency for use in field application models such as the NRC (Hanigan et al., 2018). Surprisingly, all 10 essential AA were significant determinants of MP efficiency when the model was fitted to a large production data set and the prediction errors for milk yield were reduced from an RMSE of approximately $20 \%$ to less than $10 \%$. Such a reduction in error prediction is surprising and clearly emphasizes the message that there is no single limiting AA for lactation.
A key component of the mammary responses to substrate supply and hormonal signals is the intracellular regulation of protein synthesis through intracellular signaling pathways such as the mTOR, Akt, and AMPK pathways. This signaling integrates information regarding the intracellular supply of several key AA (Appuhamy et al., 2011; Appuhamy et al., 2012), the supply of energy in the cell (Appuhamy et al., 2009), and hormonal signals indicating overall animal status, i.e., insulin (Appuhamy et al., 2011) and probably IGF-1 (Figure 4). These signaling pathways ultimately regulate protein synthesis, thus tying rates of protein synthesis to substrate supply and energy state in the animal.

As AA uptake is a function of supply to the tissue and intracellular demand, any signals that increase protein synthesis will also stimulate AA uptake through increased affinity for the needed AA (Hanigan et al., 2000; Hanigan et al., 2001; Hanigan et al., 2002; Castro et al., 2016). However, AA transport is quite complicated with more than 25 different AA transporters expressed in epithelial cells and many interactions among AA (Calvert and Shennan, 1996; Calvert et al., 1998; Bröer, 2008; Shennan et al., 1997). Therefore, although the primary driving force may be the balance of supply and demand, those forcings can be modified by the relative supply of other AA. For example, glutamine concentrations in blood are at least partially determined by metabolism in other tissues and its transport into mammary tissue is Na-dependent and, thus, can be concentrated within the cell where it can be exchanged for other AA that are not Na-dependent, including a number

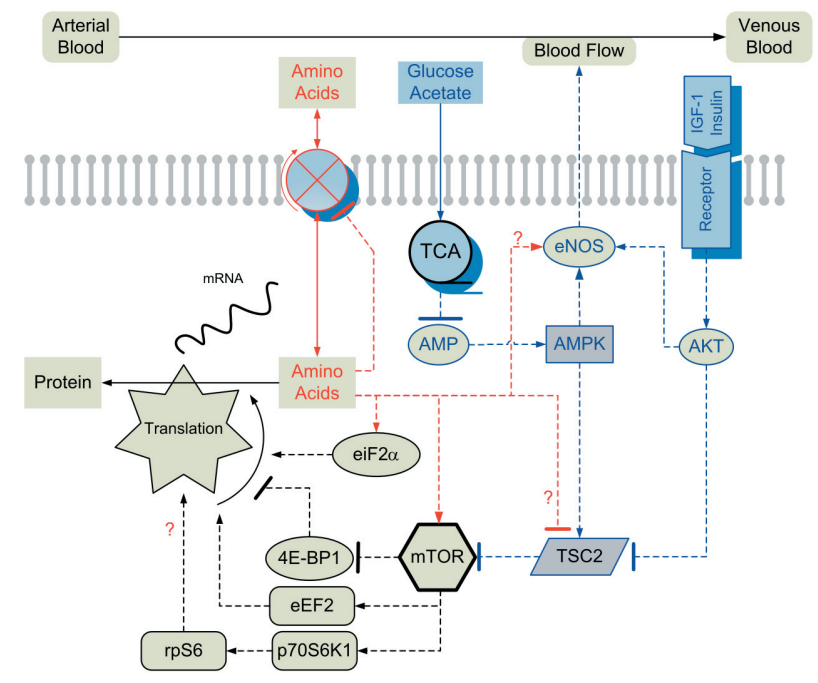

TCA - tricarboxylic acid cycle.

Figure 4 - Partial schematic of the regulation of protein synthesis by mammalian target of rapamycin (mTOR) and associated pathways. 
of the essential AA. It also may play a role in maintenance of cell volume, which has been linked to rates of protein synthesis (Meijer and Dubbelhius, 2004). Therefore, the interactive influence of glutamine or other non-essential AA on transport of essential AA could be quite varied. It remains to be determined how large these influences are.

Because the tissue can adapt its AA extraction capacity to meet intracellular AA demand, the overall rate of protein synthesis and postabsorptive AA use efficiency are functions of a combination of these regulators rather than dictated by the most limiting one.

We are currently focusing on a mechanist representation of the postabsorptive system (Myers et al., 2016). The approach utilizes tissue clearance rates for each AA, which can be calculated from arteriovenous difference data for those tissues that can be catheterized and by the difference for the remaining tissues. An initial effort using this approach was described by Hanigan et al. (1998). Such a system should provide the basis for a more robust model of postabsorptive AA metabolism that can be used for future field application development.

\section{First limiting nutrient paradigm}

The first limiting nutrient and AA concept is based on a hypothesis which has become known as the Law of the Minimum. Sprengel (1828) formulated this concept based on plant growth responses to soil minerals. However, the original thesis stated that a nutrient can limit plant growth and, when limiting, growth will be proportional to supply, which is clearly supported by volumes of data over the past 175 years. Von Liebig [see Paris (1992) for a translation] subsequently restated the hypothesis in stronger terms, indicating that if a nutrient was limiting for growth, responses to other nutrients could not occur (von Liebig, 1862). Mitchell and Block (1946) used von Liebig's extension of Sprengel's thesis to develop the concept of the order of limiting AA, which is commonly described using the analogy of a water barrel with broken staves. Based on this formulation, if any nutrient is limiting milk production, then only the addition of that nutrient to the diet will result in a positive milk yield response, e.g., the single limiting nutrient paradigm.

To determine which nutrient is most limiting, one must be able to calculate the allowable milk yield from that nutrient. That calculation is quite simple if one assumes a constant transfer efficiency, as is the case in the NRC model. However, as discussed above, transfer efficiency of AA is not fixed. Because AA removal from blood is regulated in concert with needs for milk protein synthesis (Bequette et al., 2000), the efficiency of AA transfer from the gut to milk protein is variable, thus complicating application of the calculations and perhaps bending the underlying assumptions somewhat. However, additive integration of signals arising from several AA, energy supply in the mammary cells, and hormonal concentrations at the cell surface to set rates of milk protein synthesis clearly violates the assumption that only one nutrient can limit production. If provision of more of one nutrient or hormone can offset the loss or deficiency of another, there is almost an infinite number of combinations of AA, energy substrates, and hormonal concentrations that will result in the very same amount of milk. This concept is demonstrated in vivo by the work of Rius et al. (2010) (Figure 5). More of any one AA, while all others are held constant, will push milk protein synthesis higher regardless of which is perceived to be "first limiting" (Clark et al., 1978; Hanigan et al., 2000). The recent report of Liu et al. (2017) clearly demonstrates the lack of validity of the Law of the Minimum when applied to lactational responses to amino acids. Therefore, current protein and AA requirement models for lactation inappropriately represent the underlying biology, which leads to inflated prediction errors.

The core message of this discussion is that rations can be balanced at levels well below 15\% CP, probably even below $13 \%$, if we are able to reliably match AA supply with true animal needs. Nevertheless, current models of AA requirements used in field application programs appear to be incompatible with making such predictions. We are in

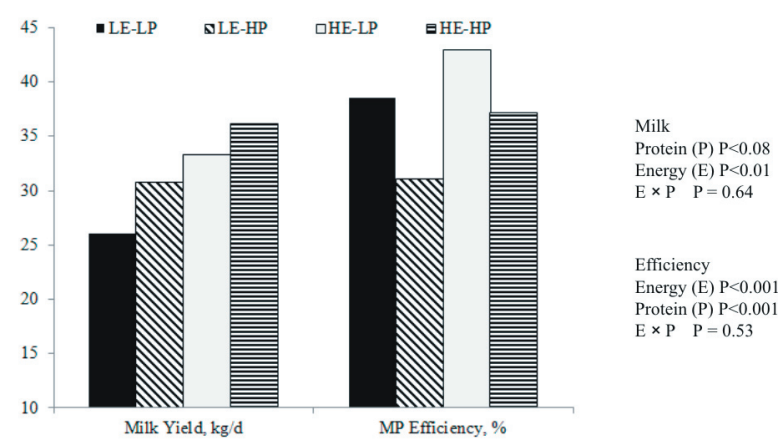

MP - metabolizable protein; LE - low metabolizabel energy; HE - high metabolizable energy; LP - low MP; HP - high MP.

Figure 5 - Milk yield and metabolizable protein efficiency of conversion to milk protein in response to varying energy and ruminally undegraded protein supply. Adapted from Rius et al. (2010). HE-HP = $1.54 \mathrm{Mcal} / \mathrm{kg}$; $11.8 \% \mathrm{MP}$; HE-LP = $1.54 \mathrm{Mcal} / \mathrm{kg}, 9.5 \% \mathrm{MP}$; LE-HP = $1.45 \mathrm{Mcal} / \mathrm{kg}, 11.8 \% \mathrm{MP}$; LE-LP $=1.45 \mathrm{Mcal} / \mathrm{kg}$, $9.5 \% \mathrm{MP}$. 
the process of devising a new prediction scheme that will be a better representation of the biology and, thus, should provide much greater accuracy, allowing us to achieve $\mathrm{N}$ efficiencies of $35 \%$ or greater in lactating cattle.

\section{References}

Abreu, A.; Carulla, J. E.; Lascano, C. E.; Díaz, T. E.; Kreuzer, M. and Hess, H. D. 2004. Effects of Sapindus saponaria fruits on ruminal fermentation and duodenal nitrogen flow of sheep fed a tropical grass diet with and without legume. Journal of Animal Science 82:1392-1400.

Appuhamy, J. A. D. R. N.; Knoebel, N. A.; Nayananjalie, W. A.; Escobar, J. and Hanigan, M. D. 2012. Isoleucine and leucine independently regulate mTOR signaling and protein synthesis in MAC-T cells and bovine mammary tissue slices. The Journal of Nutrition 142:484-491.

Appuhamy, J. A. D. R. N.; Bell, A. L.; Nayananjalie, W. A. D.; Escobar, J. and Hanigan, M. D. 2011. Essential amino acids regulate both initiation and elongation of mRNA translation independent of insulin in MAC-T cells and bovine mammary tissue slices. The Journal of Nutrition 141:1209-1215.

Appuhamy, J. A. D. R. N.; Bray, C. T.; Escobar, J. and Hanigan, M. D. 2009. Effects of acetate and essential amino acids on protein synthesis signaling in bovine mammary epithelial cells in-vitro. Journal of Dairy Science 92(e-Suppl 1):44.

Baker, D. H. 1996. Advances in amino acid nutrition and metabolism of swine and poultry. p.11-22. In: Nutrient management of food animals to enhance and protect the environment. Kornegay, E. T., ed. CRC Lewis Publishers, Boca Raton, FL.

Bateman, H. G.; Clark, J. H. and Murphy, M. R. 2005. Development of a system to predict feed protein flow to the small intestine of cattle. Journal of Dairy Science 88:282-295.

Bequette, B. J.; Hanigan, M. D.; Calder, A. G.; Reynolds, C. K.; Lobley, G. E. and MacRae, J. C. 2000. Amino acid exchange by the mammary gland of lactating goats when histidine limits milk production. Journal of Dairy Science 83:765-775.

Broderick, G. A.; Huhtanen, P.; Ahvenjarvi, S.; Reynal, S. M. and Shingfield, K. J. 2010. Quantifying ruminal nitrogen metabolism using the omasal sampling technique in cattle - a meta-analysis. Journal of Dairy Science 93:3216-3230.

Bröer, S. 2008. Amino acid transport across mammalian intestinal and renal epithelia. Physiological Reviews 88:249-286.

Calvert, D. T.; Kim, T. G.; Choung, J. J.; Burns, C. and Shennan, D. B. 1998. Characteristics of L-glutamine transport by lactating mammary tissue. Journal of Dairy Research 65:199-208.

Calvert, D. T. and Shennan, D. B. 1996. Evidence for an interaction between cationic and neutral amino acids at the blood-facing aspect of the lactating rat mammary epithelium. Journal of Dairy Research 63:25-33.

Caraviello, D. Z.; Weigel, K. A.; Fricke, P. M.; Wiltbank, M. C.; Florent, M. J.; Cook, N. B.; Nordlund, K. V.; Zwald, N. R. and Rawson, C. L. 2006. Survey of management practices on reproductive performance of dairy cattle on large US commercial farms. Journal of Dairy Science 89:4723-4735.

Castro, J. J.; Arriola Apelo, S. I.; Appuhamy, J. A. D. R. N. and Hanigan, M. D. 2016. Development of a model describing regulation of casein synthesis by the mammalian target of rapamycin (mTOR) signaling pathway in response to insulin, amino acids, and acetate. Journal of Dairy Science 99:6714-6736.

Cecava, M. J.; Merchen, N. R.; Berger, L. L. and Fahey, G. C. 1988. Effects of dietary energy level and protein source on site of digestion and duodenal nitrogen and amino acid flows in steers. Journal of Animal Science 66:961-974.

Clark, R. M.; Chandler, P. T. and Park, C. S. 1978. Limiting amino acids for milk protein synthesis by bovine mammary cells in culture. Journal of Dairy Science 61:408-413.

Cunningham, K. D.; Cecava, M. J. and Johnson, T. R. 1993. Nutrient digestion, nitrogen, and amino acid flows in lactating cows fed soybean hulls in place of forage or concentrate. Journal of Dairy Science 76:3523-3535.

Delgado, C. L. 2003. Rising consumption of meat and milk in developing countries has created a new food revolution. Journal of Nutrition 133(11 Suppl 2):3907S-3910S.

Erasmus, L. J.; Botha, P. M.; Cruywagen, C. W. and Meissner, H. H. 1994. Amino acid profile and intestinal digestibility in dairy cows of rumen-undegradable protein from various feedstuffs. Journal of Dairy Science 77:541-551.

Erasmus, L. J.; Botha, P. M. and Kistner, A. 1992. Effect of yeast culture supplement on production, rumen fermentation, and duodenal nitrogen flow in dairy cows. Journal of Dairy Science 75:3056-3065.

Gregorini, P.; Beukes, P.; Waghorn, G. Pacheco, D. and Hanigan, M. D. 2015. Development of an improved representation of rumen digesta outflow in a mechanistic and dynamic model of a dairy cow, Molly. Ecological Modelling 313:293-306.

Hanigan, M. D.; Cant, J. P.; Weakley, D. C. and Beckett, J. L. 1998. An evaluation of postabsorptive protein and amino acid metabolism in the lactating dairy cow. Journal of Dairy Science 81:3385-3401.

Hanigan, M. D.; Crompton, L. A.; Bequette, B. J.; Mills, J. A. and France, J. 2002. Modelling mammary metabolism in the dairy cow to predict milk constituent yield, with emphasis on amino acid metabolism and milk protein production: Model evaluation. Journal of Theoretical Biology 217:311-330.

Hanigan, M. D.; Crompton, L. A.; Metcalf, J. A. and France, J. 2001. Modelling mammary metabolism in the dairy cow to predict milk constituent yield, with emphasis on amino acid metabolism and milk protein production: Model construction. Journal of Theoretical Biology 213:223-239.

Hanigan, M. D.; Lapierre, H.; Martineau, R. and Myers, A. M. 2018. Predicting milk protein production from amino acid supply. Journal of Dairy Science 101(Suppl. 2):410.

Hanigan, M. D.; France, J.; Crompton, L. A. and Bequette, B. J. 2000. Evaluation of a representation of the limiting amino acid theory for milk protein synthesis. p.127-144. In: Modelling nutrient utilization in farm animals. CABI Publishing, Wallingford, UK.

Haque, M. N.; Rulquin, H.; Andrade, A.; Faverdin, P.; Peyraud, J. L. and Lemosquet, S. 2012. Milk protein synthesis in response to the provision of an "ideal" amino acid profile at 2 levels of metabolizable protein supply in dairy cows. Journal of Dairy Science 95:5876-5887.

Hertel, T. W. 2011. The global supply and demand for agricultural land in 2050: A perfect storm in the making? American Journal of Agricultural Economics 93:259-275.

Hristov, A. N.; Price, W. J. and Shafii, B. 2004. A meta-analysis examining the relationship among dietary factors, dry matter intake, and milk and milk protein yield in dairy cows. Journal of Dairy Science 87:2184-2196.

Knapp, J. R. 2009. The good news: Feed costs have declined over the past year. Buckeye News.

Korhonen, M.; Vanhatalo, A.; Varvikko, T. and Huhtanen, P. 2000. Responses to graded postruminal doses of histidine in dairy cows fed grass silage diets. Journal of Dairy Science 83:2596-2608.

Krizsan, S. J.; Ahvenjarvi, S. and Huhtanen, P. 2010. A meta-analysis of passage rate estimated by rumen evacuation with cattle and evaluation of passage rate prediction models. Journal of Dairy Science 93:5890-5901. 
Lapierre, H.; Lobley, G. E.; Ouellet, D. R.; Doepel, L. and Pacheco, D. 2007. Amino acid requirements for lactating dairy cows: Reconciling predictive models and biology. p.39-59. In: Proceedings of the Cornell Nutrition Conference for Feed Manufacturers. Department of Animal Science, Cornell University, New York.

Liu, G. M.; Hanigan, M. D.; Lin, X. Y.; Zhao, K; Jiang, F. G.; White, R. R.; Wang, Y.; Hu, Z. Y. and Wang, Z. H. 2017. Methionine, leucine, isoleucine, or threonine effects on mammary cell signaling and pup growth in lactating mice. Journal of Dairy Science 100:4038-4050.

Maxin, G.; Ouellet, D. R. and Lapierre, H. 2013. Effect of substitution of soybean meal by canola meal or distillers grains in dairy rations on amino acid and glucose availability. Journal of Dairy Science 96:7806-7817.

Meijer, A. J. and Dubbelhuis, P. F. 2004. Amino acid signalling and the integration of metabolism. Biochemical and Biophysical Research Communications 313:397-403.

Mitchell, H. H. and Block, R. J. 1946. Some relationships between the amino acid contents of proteins and their nutritive values for the rat. The Journal of Biological Chemistry 163:599-620.

Myers, A. J.; White, R. R.; Lapierre, H.; Martineau, R.; France, J. and Hanigan, M. D. 2016. Modeling transfer efficiency of essential amino acids from gut absorption to milk protein. Canadian Journal of Animal Science 96:629-630.

Noftsger, S. and St-Pierre, N. R. 2003. Supplementation of methionine and selection of highly digestible rumen undegradable protein to improve nitrogen efficiency for milk production. Journal of Dairy Science 86:958-969.

NRC - National Research Council. 1989. Nutrient requirements of dairy cattle. 6th ed. National Academy Press, Washington, DC.

NRC - National Research Council. 2001. Nutrient requirements of dairy cattle. 7th rev. National Academy Press, Washington, DC.

Paris, Q. 1992. The von Liebig hypothesis. American Journal of Agricultural Economics 74:1019-1028.

Reynolds, C. K. and Kristensen, N. B. 2008. Nitrogen recycling through the gut and the nitrogen economy of ruminants: An asynchronous symbiosis. Journal of Animal Science 86(14_suppl): E293-305.

Rius, A. G.; McGilliard, M. L.; Umberger, C. A. and Hanigan, M. D. 2010. Interactions of energy and predicted metabolizable protein in determining nitrogen efficiency in the lactating dairy cow. Journal of Dairy Science 93:2034-2043.

Rockström, J.; Falkenmark, M.; Karlberg, L.; Hoff, H.; Rost, S. and Gerten, D. 2009. Future water availability for global food production: The potential of green water for increasing resilience to global change. Water Resources Research 45:W00-A12.

Roman-Garcia, Y.; White, R. R. and Firkins, J. L. 2016. Metaanalysis of postruminal microbial nitrogen flows in dairy cattle. I. Derivation of equations. Journal of Dairy Science 99:7918-7931.
Rulquin, H.; Pisulewski, P. M.; Verite, R. and Guinard, J. 1993. Milk production and composition as a function of postruminal lysine and methionine supply: A nutrient-response approach. Livestock Production Science 37:69-90.

Shennan, D. B.; Millar, I. D. and Calvert, D. T. 1997. Mammarytissue amino acid transport systems. Proceedings of the Nutrition Society 56(1A):177-191.

Sprengel, C. 1828. Von den substanzen der ackerkrume und des untergrundes (about the substances in the plow layer and the subsoil). Journal für Technische und Ökonomische Chemie 3:42-99.

St-Pierre, N. 2012. The costs of nutrients, comparison of feedstuffs prices and the current dairy situation. Buckeye News.

U.S. Census Bureau. 2008. Total midyear population for the world: 1950-2050. U.S. Census Bureau, Washington, D.C.

von Liebig, J. 1862. Die chemie in ihrer anwendung auf agricultur und physiologie. Vol. II. 7. Aufl ed. Friedrich Vieweg, Braunschweig.

White, R. R. 2016. Increasing energy and protein use efficiency improves opportunities to decrease land use, water use, and greenhouse gas emissions from dairy production. Agricultural Systems 146:20-29.

White, R. R.; Roman-Garcia, Y. and Firkins, J. L. 2016a. Metaanalysis of postruminal microbial nitrogen flows in dairy cattle. II. Approaches to and implications of more mechanistic prediction. Journal of Dairy Science 99:7932-7944.

White, R. R.; Roman-Garcia, Y.; Firkins, J. L.; Kononoff, P.; VandeHaar, M. J.; Tran, H.; McGill, T.; Garnett, R. and Hanigan, M. D. 2017a. Evaluation of the National Research Council (2001) dairy model and derivation of new prediction equations. 2. Rumen degradable and undegradable protein. Journal of Dairy Science 100:3611-3627.

White, R. R.; Roman-Garcia, Y.; Firkins, J. L.; VandeHaar, M. J.; Armentano, L. E.; McGill, T.; Garnett, R. L.and Hanigan, M. D. 2016b. Evaluation of the 2001 dairy NRC and derivation of new prediction equations. In: Proceedings of the 5th EAAP International Symposium on Energy and Protein Metabolism. Wageningen Academic Publishers (EAAP publication 137), Krakow, Poland.

White, R. R.; Roman-Garcia, Y.; Firkins, J. L.; VandeHaar, M. J.; Armentano, L. E.; Weiss, W. P.; McGill, T.; Garnett, R. and Hanigan, M. D. 2017b. Evaluation of the National Research Council (2001) dairy model and derivation of new prediction equations. 1. Digestibility of fiber, fat, protein, and nonfiber carbohydrate. Journal of Dairy Science 100:3591-3610.

Whitelaw, F. G.; Milne, J. S.; Orskov, E. R. and Smith, J. S. 1986. The nitrogen and energy metabolism of lactating cows given abomasal infusions of casein. British Journal of Nutrition 55:537-556. 